\title{
A Comparison of Two Techniques for Counting Cellulolytic Rumen Bacteria
}

\author{
By N. O. VAN GYLSWYK \\ National Chemical Research Laboratory, South African Council for Scientific and \\ Industrial Research, Pretoria, Republic of South Africa
}

(Accepted for publication 23 October 1969)

SUMMARY

Cellulolytic bacteria were counted by the 'direct' method; estimated from the number of clearings produced in films of cellulose-containing agar medium inoculated with high dilutions of rumen ingesta and by the 'indirect' method; numbers were calculated from 'total culturable' counts on films of a non-specific agar medium and from the percentages of bacteria found to be cellulolytic after isolation in pure culture. The two methods yielded similar results.

Two methods have been mainly used to determine the numbers of cellulolytic bacteria in the rumen. In the 'direct' method as used for instance by Hungate (I947, 1950, 1957), Kistner (1960), Gilchrist \& Kistner (1962), Kistner, Gouws \& Gilchrist (1962), Gilchrist (1965) and De Wet (1966), colony counts of cellulolytic bacteria are made on a selective medium containing finely divided cellulose. The cellulolytic colonies were identified by the circular clearings formed through the action of cellulase secreted by the bacteria. The number of clearings gives a direct estimate of the numbers of cellulolytic bacteria in the sample. In the 'indirect' method used for instance by Bryant \& Burkey (I953b), Bryant, Small, Bouma \& Robinson (1958) and De Wet (I966) an agar medium designed to support the growth of the widest possible spectrum of rumen bacteria was inoculated with high dilutions of rumen contents. Well-spaced colonies were picked non-selectively and transferred directly to agar slants of nonspecific medium. All the isolates obtained from a number of samples, collected at intervals from an animal conditioned to a particular diet, were then examined for cellulolytic activity. From the percentage of isolates capable of hydrolysing cellulose and the mean colony count on the non-selective medium the mean level of cellulolytic bacteria in the rumen was calculated.

When comparing the counts of cellulolytic bacteria by the two methods, counts by the 'indirect' method were almost always higher than those obtained by the 'direct' method. In Table I the values for counts by the 'direct' method range from about $\mathrm{I} \times 10^{6}$ to $20 \times 10^{6}$ bacteria (colonies) $/ \mathrm{ml}$. whereas those by the 'indirect' method are within the range $\mathrm{I} \times 10^{6}$ to $500 \times 10^{6} / \mathrm{ml}$. In no case, however, were counts by the two methods made on the same sample. Although De Wet examined samples from the same animals on the same diets, the samples were taken on different dates. To decide whether these differences are due to inherent differences in counting techniques, or are due to differences between animals or between diets, a comparison of the two methods was made on the same samples from sheep on three high-roughage 
diets. This work was done in the course of studies on the cellulolytic flora of sheep on different diets. To get enough isolates in the case of the 'indirect' method in Expts. I and 3 it was necessary to obtain them from more than one sheep on a given ration. However, for the purpose of this study this was not considered to be important.

Table I. Numbers of cellulolytic rumen bacteria found by different authors using the 'direct' and 'indirect' counting methods

\begin{tabular}{|c|c|c|c|}
\hline Reference & $\begin{array}{l}\text { Animals } \\
\text { used }\end{array}$ & Ration & $\begin{array}{l}\text { Numbers of cellulolyti } \\
\text { bacteria/ml. or } \mathrm{g} . \\
\left(\times 10^{6}\right)\end{array}$ \\
\hline \multicolumn{4}{|l|}{ Direct method } \\
\hline Hungate (1957) & Cows & $\begin{array}{l}\text { Timothy hay + different } \\
\text { supplements }\end{array}$ & $\begin{array}{l}2.87 \text { (I2)* } \\
5.57 \text { (I2) } \\
3.00 \text { (I2) } \\
2.12 \text { (II) } \\
2.27 \text { (I2) } \\
3.14 \text { (9) } \\
1.88 \text { (I2) } \\
0.83 \text { (13) }\end{array}$ \\
\hline Kistner (1960) & Sheep & Lucerne hay & $\begin{array}{l}8.2(2-22) \dagger(\mathrm{II}) \\
18 \cdot 0(13 \cdot 75-25 \cdot 6)(5) \\
20 \cdot 5(19 \cdot 25-2 \mathrm{I} \cdot 5)(4)\end{array}$ \\
\hline Gilchrist \& Kistner (1962) & Sheep & Poor teff hay & $3.2(0.1-10)(17)$ \\
\hline Kistner et al. (1962) & Sheep & Lucerne hay & $17(I-39)(19)$ \\
\hline Gilchrist (1965) & Sheep & $\begin{array}{l}\text { Lucerne hay } \\
\text { Teff hay } \\
\text { Teff hay+urea } \\
\text { + molasses }\end{array}$ & $\begin{array}{l}5(4-6)(3) \\
2 \cdot 03(0 \cdot I-5)(3) \\
I \cdot 64(0 \cdot 06-3)(4)\end{array}$ \\
\hline De Wet (1966) & Sheep & $\begin{array}{l}\text { Wheat straw } \\
\text { Wheat straw + urea } \\
\text { + molasses }\end{array}$ & $\begin{array}{l}0.87(0.01-5)(20) \\
15(2.5-50)(35)\end{array}$ \\
\hline \multicolumn{4}{|l|}{ Indirect method } \\
\hline Bryant \& Burkey (1953b) & Cows & $\begin{array}{l}\text { Alfalfa hay }+ \text { concen- } \\
\text { trates } \\
\text { Wheat straw } \\
\text { Concentrates } \\
\text { Alfalfa hay }\end{array}$ & $\begin{array}{l}\text { II3, } 294 \\
502 \\
338 \\
258, \text { I I } 4\end{array}$ \\
\hline Bryant et al. (1958) & Calves & $\begin{array}{l}\text { Alfalfa hay + grain } \\
\text { mixture }\end{array}$ & $\begin{array}{c}100 \\
\text { I } 2 \\
110 \\
320 \\
430 \\
62\end{array}$ \\
\hline De Wet (1966) & Sheep & $\begin{array}{l}\text { Wheat straw } \\
\text { Wheat straw + urea } \\
\text { + molasses }\end{array}$ & $\begin{array}{l}4 \cdot \mathbf{I} \\
\mathrm{I} 43\end{array}$ \\
\hline
\end{tabular}

\section{METHODS}

Animals. These were Merino wethers fitted with permanent rumen fistulas.

Diets. The diet for Expt. I consisted of $1500 \mathrm{~g}$. of teff hay daily. For Expt. 2 the ration consisted of $1200 \mathrm{~g}$. of teff hay, supplemented with $10 \mathrm{~g}$. urea and $80 \mathrm{~g}$. glucose in I 1. water which was given per fistula at about 09.00 a.m. In Expt. 3 the sheep were fed I $200 \mathrm{~g}$. of treated teff hay daily, the crude protein content of which had been raised 
from 3.7 to $10.7 \%$ by application of spray-dried egg albumin. Each ration was supplemented with a balanced mineral+trace element lick and vitamin A. In all three experiments the hay was given to the sheep as one feed at about 08.15 a.m. The trace element lick (about 15 g.) was given separately at the same time while vitamin A was given once/week. The sheep were conditioned to the diets for at least 6 weeks before sampling of rumen ingesta began.

Sampling and treatment of rumen ingesta. Samples of rumen ingesta for bacterial counts were taken through the fistula with a sampling tube about $2.5 \mathrm{hr}$ after feeding. On sampling days water was withheld from the sheep from the time of feeding until the sample had been drawn. Ingesta were generally not drawn more often than once/week from a sheep. In Expts. I and 2 about $150 \mathrm{ml}$. ingesta were withdrawn. The sample was blended with an Ultra Turrax, type TP I8/2 homogenizer (Janke \& Kunkel, Staufen i. Br., West Germany) operating at $20,000 \mathrm{rev} . / \mathrm{min}$. for $30 \mathrm{sec}$. with the container cooled in ice. A ro g. subsample was weighed out and then diluted with $90 \mathrm{ml}$. of an anaerobic diluting solution similar to that used by Bryant \& Burkey (I953a) except that it contained indigo carmine instead of resazurin. This mixture was again treated with the homogenizer for $60 \mathrm{sec}$. to ensure maximal release of organisms from solid particles of ingesta and perhaps to decrease the size of aggregates of bacteria. For Expt. 3, in an attempt to obtain a truly representative sample from the rumen, about $600 \mathrm{ml}$. ingesta were withdrawn. This was mixed by shaking in a stoppered bottle; a I50 ml. sample, treated as described above, was used for making colony counts.

Cellulolytic counts by the 'direct method'. For these counts $\mathrm{I} \cdot 2 \%(\mathrm{w} / \mathrm{v})$ ball-milled Whatman no. I filter paper was substituted for the carboyhdrates in the medium of Bryant \& Robinson (I96I) for obtaining 'total culturable' counts. Indigo carmine $(0.0005 \%)$ was substituted for resazurin. The filter paper cellulose was prepared as follows: $12 \mathrm{~g}$. shredded filter paper and $600 \mathrm{ml}$. deionized water, were placed in a ball mill of about $\mathrm{I} 1$. capacity and this was milled with a mixed charge of porcelain balls for about $72 \mathrm{hr}$ at $57 \mathrm{rev} . / \mathrm{min}$. Roll bottles of $7 \mathrm{ml}$. capacity, spun mechanically, were used as culture vessels (Kistner, 1960). Colonies of cellulolytic bacteria were counted after incubation for 4 weeks at $39^{\circ}$.

'Total culturable' and 'indirect' cellulolytic counts. Methods for obtaining colony counts of 'total culturable' bacteria were essentially those of Bryant \& Burkey (I953a) as modified by Bryant \& Robinson (I96I). The medium (GCSX medium) contained $0.05 \%$ each of glucose, cellobiose, starch and xylan, with indigo carmine $(0.0005 \%)$ instead of resazurin. Roll bottles were used as for the 'direct' cellulolytic counts. Colonies of 'total culturable' bacteria were counted after incubation for I week at $39^{\circ}$.

For the 'indirect' cellulolytic counts generally all the well-isolated colonies were picked from one or more roll bottles containing GCSX medium inoculated with the $\mathrm{IO}^{-7}$ or $1 \mathrm{O}^{-8}$ dilutions of the samples. Inoculum was transferred to slopes of GCSX medium. The cultures were tested for ability to hydrolyse cellulose in a medium containing rumen fluid and $\mathrm{I} \cdot 2 \%(\mathrm{w} / \mathrm{v})$ ground $\alpha$-cellulose prepared from teff hay. Inoculated bottles containing this medium were incubated for at least 4 weeks, after which samples of the well-mixed medium were placed in Wintrobe Hematocrit Tubes (Type A-2456, Clay Adams, Inc., N.Y.) and centrifuged for $30 \mathrm{~min}$. at about $1500 \mathrm{~g}$. Cultures showing more than $10 \%$ decrease in volume of cellulose when compared 
with readings for uninoculated medium were considered to be cellulolytic. Ten $\%$ was considered a minimal value consistent with reliable interpretation.

Table 2. Counts of 'total culturable' and cellulolytic bacteria made by 'direct' counting method on samples of rumen ingesta from sheep fed teff hay diets

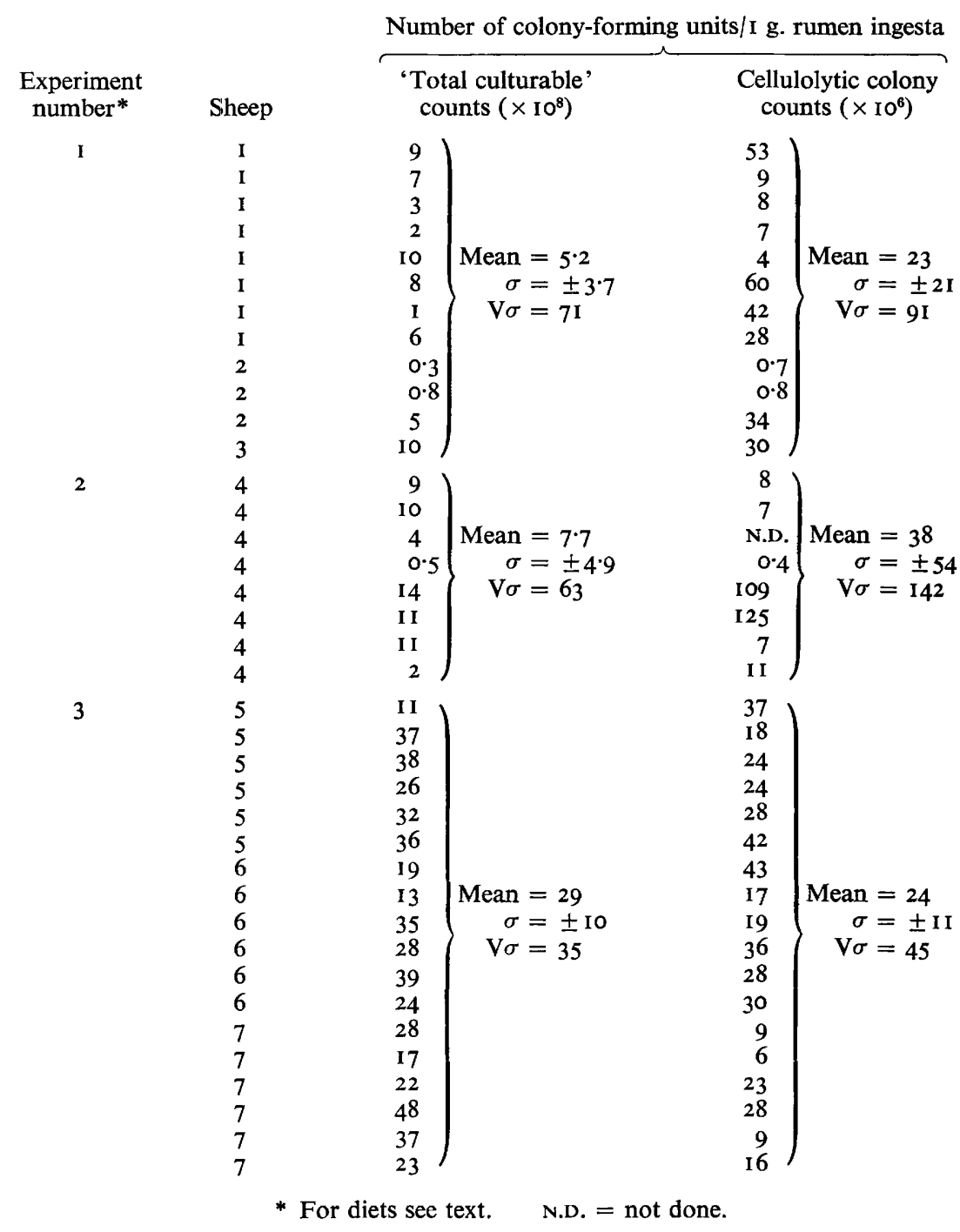

\section{RESULTS}

The results obtained for the 'total culturable' and 'direct' cellulolytic counts for the three experiments are given in Table 2. Table 3 gives a comparison of the results for the 'direct' and the 'indirect' methods of counting cellulolytic bacteria. A remarkably close agreement existed in the results obtained with the two methods in 
Expt. 3. The differences between the results for the methods in Expts. I and 2, although approaching twofold, were not considered to be excessive. The percentages of cellulolytic bacteria calculated from the 'direct' and 'indirect' counts were, respectively: Expt. I, 4.4 and $7 \cdot 2$; Expt. $2,4.9$ and 3.0 ; Expt. 3, 0.8 and 0.8 .

Table 3. Derivation of 'indirect' cellulolytic counts and comparison with 'direct' cellulolytic counts made on samples of rumen ingesta from sheep fed teff hay diets

\begin{tabular}{|c|c|c|c|c|c|c|c|}
\hline & & & & Indirect $\mathrm{n}$ & lethod & & $\begin{array}{l}\text { Direct } \\
\text { method }\end{array}$ \\
\hline $\begin{array}{l}\text { Experi- } \\
\text { ment } \\
\text { number* }\end{array}$ & Sheep & $\begin{array}{l}\text { Number } \\
\text { of } \\
\text { colonies } \\
\text { picked } \\
\text { from non- } \\
\text { specific } \\
\text { medium }\end{array}$ & $\begin{array}{l}\text { Number } \\
\text { of } \\
\text { colonies } \\
\text { found } \\
\text { to be } \\
\text { cellulolytic }\end{array}$ & $\begin{array}{l}\text { Cellulo- } \\
\text { lytic } \\
\text { bacteria } \\
\text { (\% total } \\
\text { number of } \\
\text { colonies } \\
\text { picked) }\end{array}$ & $\begin{array}{c}\text { Mean } \\
\text { 'total } \\
\text { culturable' } \\
\text { counts } \uparrow\end{array}$ & $\begin{array}{c}\text { Mean } \\
\text { number of } \\
\text { cellulolytic } \\
\text { bacteria/I g. } \\
\text { rumen } \\
\text { ingesta } \\
\text { (calculated) }\end{array}$ & $\begin{array}{c}\text { Mean } \\
\text { number of } \\
\text { cellulolytic } \\
\text { bacteria/I } \mathrm{g} \text {. } \\
\text { rumen } \\
\text { ingesta } \dagger\end{array}$ \\
\hline $\begin{array}{l}\text { I } \\
2 \\
3\end{array}$ & $\begin{array}{l}1,2,3 \\
4 \\
5,6,7\end{array}$ & $\begin{array}{l}29 I \\
168 \\
265\end{array}$ & $\begin{array}{r}2 \mathrm{I} \\
5 \\
2\end{array}$ & $\begin{array}{l}7 \cdot 2 \\
3 \cdot 0 \\
0 \cdot 8\end{array}$ & $\begin{array}{r}5.2 \times 10^{8} \\
7.7 \times 10^{8} \\
29 \times 10^{8}\end{array}$ & $\begin{array}{l}37 \times 10^{6} \\
23 \times 10^{6} \\
23 \times 10^{6}\end{array}$ & $\begin{array}{l}23 \times 10^{6} \\
38 \times 10^{6} \\
24 \times 10^{6}\end{array}$ \\
\hline
\end{tabular}

\section{DISCUSSION}

In the present study, the 'direct' and 'indirect' methods of colony counts of cellulolytic rumen bacteria yielded essentially the same results when applied to the same samples. This does not exclude the possibility that the differences between the counts reported by various workers using one or other of the methods (Table I) were partly due to differences in counting techniques. Both methods are subject to particular types of errors. In the case of the 'direct' method, the nature of the cellulose substrate may influence the counts. Certain forms of cellulose are not readily utilized by all strains of cellulolytic rumen bacteria (Halliwell \& Bryant, 1963; Hungate, 1966; Shane, I966). Moreover, if the cellulose substrate is not sufficiently ground the substrate is not homogeneously distributed throughout the medium. This can make detection of small clearings difficult, and it may also prevent the development of colonies from cellulolytic bacteria which are not near to the cellulose substrate. Low cellulolytic counts may also result from competition between cellulolytic bacteria for limiting amounts of accessory nutrients, or from accumulation of metabolic end-products, which prevent some of the bacteria from developing into visible colonies. This is often the case in cultures inoculated with lower sample dilutions.

In the case of 'indirect' counts, the method of determining cellulolysis may influence the results. The method described above showed up weakly cellulolytic strains which were previously missed when the method of Bryant \& Burkey (1953a) was used for detecting cellulolysis. The extent to which the medium for the 'total culturable' counts supports the growth of all viable bacteria in the sample of rumen contents should not affect the 'indirect' counts of cellulolytic bacteria, provided that the medium meets the environmental requirements of all the cellulolytic species. However, the composition of the medium may affect the apparent percentage of cellulolytic bacteria. Thus the high percentage of cellulolytic bacteria in rumen contents of cows on various 
diets reported by Bryant \& Burkey (1953b) may be related to the fact that these authors included neither starch nor maltose in their medium for 'total culturable' counts and therefore excluded at least one important specifically amylolytic, organism namely Bacteroides amylophilus. The 'indirect' method becomes particularly inefficient when the cellulolytic organisms form a small percentage of the 'total culturable' bacterial population. Unless a very large number of isolations is made under these circumstances, considerable errors in cellulolytic counts may occur. However the 'indirect' method does give the proportion of the total population which is cellulolytic, although it is easier to obtain this information by making 'direct cellulolytic counts and total culturable' counts on the same sample. In the present work, percentage values for cellulolytic bacteria were obtained by both methods and the figures for the two methods were in close agreement.

Another factor which can profoundly influence the counts of cellulolytic bacteria obtained by different workers is the method of obtaining the sample. A large proportion of the cellulolytic bacteria in the rumen are attached to the food particles (Hungate, 1966) and may therefore be excluded by straining the ingesta. There is, however, no generally accepted method of collecting and preparing samples of ingesta for making counts. The influence of different procedures on the counts of cellulolytic and other groups of bacteria in the rumen is being investigated in this laboratory.

The time of day at which the samples are taken can influence the counts in two ways: (I) it may affect the proportion of organisms bound to food particles and hence enhance or decrease differences due to the method of sample preparation; (2) it may also reflect diurnal changes in the actual numbers of bacteria in the rumen. Thus the results of 'total culturable' counts on rumen contents of a cow fed a grain ration or a hay ration once a day, as reported by Bryant \& Robinson (196I), showed marked diurnal variations with the former and very little change with the latter diet. Assuming that the cellulolytic counts showed a similar trend on each diet the time of sampling could exert a significant influence on the counts in the case of the grain ration, while it would have little effect with the hay diet. It is desirable that differences in counts associated with these different methods should be eliminated as far as possible, or at least be capable of assessment, so that the results of different workers with diets of different composition, in different localities, or with different species of ruminants can be compared with confidence.

The author wishes to thank Dr A. Kistner for advice and interest in this work and Miss W. Jansen van Ryssen and Miss A. F. S. Schalekamp for technical assistance. Thanks are also due to the Chief, Veterinary Research Institute, Onderstepoort, for providing the facilities for the work.

\section{REFERENCES}

Bryant, M. P. \& Burkey, L. A. (1953a). Cultural methods and some characteristics of some of the more numerous groups of bacteria in the bovine rumen. Journal of Dairy Science 36, 205.

BRYANT, M. P. \& BurkeY, L. A. (1953b). Numbers and some predominant groups of bacteria in the rumen of cows fed different rations. Journal of Dairy Science 36, 218.

BryaNT, M. P. \& RoBINson, I. M. (I96I). An improved non-selective culture medium for ruminal bacteria and its use in determining diurnal variation in numbers of bacteria in the rumen. Journal of Dairy Science 44, 1446.

Bryant, M. P., Small, N., Bouma, C. \& Robinson, I. M. (1958). Characteristics of ruminal anaerobic cellulolytic cocci and Cillobacterium cellulosolvens n.sp. Journal of Bacteriology 76, 529. 
DE WET, J. G. (I966). Cellulolytic rumen bacteria fermenting wheat straw. M.Sc. Thesis. University of Stellenbosch, Republic of South Africa.

Gilchrist, F. M. C. (1965). Influence of diet on functional groups of rumen bacteria fermenting carbohydrates and lactate. In Science and Medicine in Central Africa. Ed. by G. J. Snowball. Oxford: Pergamon Press.

Gilchrist, F. M. C. \& Kistner, A. (I962). Bacteria of the ovine rumen. I. The composition of the population on a diet of poor teff hay. Journal of Agricultural Science, Cambridge 59, 77.

Halliwell, G. \& Bryant, M. P. (I963). The cellulolytic activity of pure strains of bacteria from the rumen of cattle. Journal of General Microbiology 32, 44I.

Hungate, R. E. (I947). Studies on cellulose fermentation. III. The culture and isolation of cellulosedecomposing bacteria from the rumen of cattle. Journal of Bacteriology 53, 631 .

Hungate, R. E. (1950). The anaerobic mesophilic cellulolytic bacteria. Bacteriological Reviews 14 , I.

Hungate, R. E. (1957). Micro-organisms in the rumen of cattle fed a constant ration. Canadian Journal of Microbiology 3, 289 .

Hungate, R. E. (1966). The Rumen and its Microbes. New York and London: Academic Press.

KISTNER, A. (I960). An improved method for viable counts of bacteria of the ovine rumen which ferment carbohydrates. Journal of General Microbiology 23, 565 .

KistNer, A., Gouws, L. \& Gilchrist, F. M. C. (I962). Bacteria of the ovine rumen. II. The functional groups fermenting carbohydrates and lactate on a diet of lucerne (Medicago sativa) hay. Journal of Agriculture Science, Cambridge 59, 85.

SHANE, B. S. (1966). The predominant cellulolytic rumen bacteria of sheep fed low-protein teff hay. Ph.D. Thesis, University of the Witwatersrand, Johannesburg, Republic of South Africa. 